\title{
TELEWORKING IN SMALL AND MEDIUM ENTERPRISES (SMES) BEFORE THE ONSET OF CORONAVIRUS CRISIS IN THE CZECH REPUBLIC
}

\author{
Jaroslav Vrchota* \\ Monika Mařiková** \\ Petr ŘRehor***
}

Received: 6. 4. 2020

Preliminary communication

Accepted: 25. 11. 2020

UDC 005.961:654](437.3)

DOI: https://doi.org/10.30924/mjcmi.25.2.8

\begin{abstract}
Due to the new information and commuof the total of 31 factors, six factors have been nication technologies, it is now possible to disconnect work from space and time and to take advantage of new ways of organizing work. One of the options is teleworking (TW), currently being implemented throughout Europe due to the condition created by the coronavirus pandemic. The aim of the paper is twofold: (i) to analyse a range of factors (size of the enterprise; foreign owner; written strategy; project-driven enterprise; disabilities; work-life balance; benefits, lack of workers, illness, lower cost, relax at work and comfort; renting space, IT level) influencing the duration of $T W$ implementation in the small and medium-sized enterprises (SMEs) and (ii) to proved to have a different impact on the duration of TW implementation (TW implementation due to higher efficiency; monitoring is performed only according to the results; the managers see the disadvantage of $T W$ in its possible misuse; the enterprises use internal $T W$ regulations; the managers see the main advantage as higher operational flexibility; the introduction of $T W$, due to the balance of work and family life). All together, 44,000 SMEs in the Czech Republic were invited into the research. The data were collected from 1,018 enterprises, with $60 \%$ of the enterprises using $T W$ actively; on average, these enterprises have been using it for seven years.
\end{abstract} better define the differences between the SMEs where $T W$ was introduced in a short time, and those introducing it over a longer period. Out

Keywords: teleworking, career, Small and Medium Enterprises (SMEs), management, homeworking

\footnotetext{
* Jaroslav Vrchota, PhD, Assistant Professor, Department of Management, Faculty of Economics, University of South Bohemia in Č. Budějovice, Studentská 15, 37005 České Budějovice, Czech Republic, Phone +420 38777 2698, Email: vrchota@ef.jcu.cz, ORCID: https://orcid.org/0000-0002-8363-3131

** Monika Maříková, Department of Management, Faculty of Economics, University of South Bohemia in Č. Budějovice, Studentská 15, 37005 České Budějovice, Czech Republic, Phone +420 38777 2844, Email: marikova@ef.jcu.cz, ORCID: https://orcid.org/0000-0002-9054-4559

*** Petr Řehoř, PhD, Associate Professor, Department of Management, Faculty of Economics, University of South Bohemia in Č. Budějovice, Studentská 15, 37005 České Budějovice, Czech Republic, Phone +420 387772495 , Email: rehor@ef.jcu.cz, ORCID: https://orcid.org/0000-0003-2438-3395
} 


\section{Journal of Contemporary Management Issues}

\section{INTRODUCTION}

The development of teleworking (TW), defined by the use of modern information and communication technologies and the mutual trust between an employer and an employee, is not hampered by the reluctance of employees, but rather by the reluctance of the enterprises. Unlike Western Europe and the US, the culture in the Czech Republic (CR) is still not fully prepared for work flexibility. At the same time, the concept of TW allows a better balance of personal and professional life. TW is a fullfledged part of the "work mix" and can be greatly complemented by office work, but it must always be adapted to the specific possibilities of the employer and the employee. This is, also, supported by government measures in all EU countries, limiting social contacts, due to the coronavirus infection and recommend working from home, i.e. creating home offices. As the current situation shows, companies already engaged in TW are ahead of the market.

TW is currently a widely discussed topic and an important element of work routines, becoming a standard issue for the workers. For example, between 2005 and 2011, the number of teleworkers in the US increased by $73 \%$ (Fried \& Hansson, 2014). Such part of professional life is, therefore, to be perceived as very dynamic. A significant increase in TW is expected for the Czech Republic, where the number of teleworkers amounted to $4 \%$ in 2018 . When compared to the amount of $2.6 \%$ in 2010 , which is still by $1.4 \%$ less than is the EU average. Eurostat statistics show that TW is most common in the Netherlands (14\%), Finland (13.3\%) and Luxembourg (12.5\%). Also, it is more common in countries, adopting the Euro currency, with more women practicing it than men (specifically, there were $4.6 \%$ women in the Czech Republic in 2018) (Eurostat, 2020). TW seems to offer an alternative for the women, who want to pursue their careers after giving birth and do not want to lose their jobs during the parental leave. Although parttime work and working shorter hours can help mothers reconcile work with family requirements, this may also result in longterm consequences for one's career. TW offers the possibility of minimizing such loss (Chung \& van der Horst, 2018).

\section{THEORETICAL PERSPECTIVES AND EMPIRICAL BACKGROUND}

\subsection{Definition of $\mathrm{TW}$}

TW can be defined as "a work arrangement in which workers perform their regular work at a site other than the ordinary workplace, supported by technological connections" (Fitzer, 1997). In its study, the European Commission defines $\mathrm{TW}$ as "flexible working time arrangements and gender equality" (Plantenga et al., 2010). By Telework Enhancement Act (USA: Telework Enhancement Act of 2010 Chapter 65 - Telework, 2010), TW refers to " $a$ work flexibility arrangement under which an employee performs the duties and responsibilities of such employee's position, and other authorized activities, from an approved worksite other than the location from which the employee would otherwise work". TW is, also, described in the literature as the ability to perform one's duties regularly from home or another remote location, provided that this remote location is suitably equipped with computer technology, which ensures the subsequent transfer of data and documents to the organization itself (Caillier, 2012). It is evident that, in a time rich in technological advances, there is no problem working almost anywhere, and the organizations, regardless of their size 
and area of operation, are becoming aware of it (Smith et al., 2018).

\subsection{Overview of the $T W$ trends in the modern economies}

TW is characterised by both benefits and drawbacks for employers, as well as for employees. Likewise, there are many forms of TW, ranging from occasional out-of-office work, to freelancing in co-working centres, to working on the road. The share of Czech employers offering TW has long been between one quarter and one third of all enterprises. However, the share of teleworkers is constantly growing, as reported by Eurostat results $(2.6 \%$ in $2010 ; 4 \%$ in 2018$)$. KPMG (2013) finds that one third of Czech enterprises offer TW. More than three-quarters of Czechs would like to work in this way, however only $12 \%$ of employees use TW. Some older Czech surveys among the employers, related to TW, are summarized in a study by the Research Institute of Labour and Social Affairs in the study of Flexible Forms of Work in Selected EU Countries (Kotíková et al., 2013).

According to the survey of the Association of SMEs and Crafts of the Czech Republic, $30 \%$ of the enterprises offered the opportunity to telework (AMSP, 2010). A similar share $(25 \%)$, of the enterprises using TW, was confirmed by another older study (Václavková et al., 2007). The results of the 2013 Regus study (Regus, 2017), including 26,000 managers from 90 countries, show that $48 \%$ of the managers engage in TW for at least half of a week. Of these, 55\% assume that teleworkers can be managed effectively. According to Regus (2017), the role of trust in employees and their freedom is crucial in TW. When these elements are applied, TW brings the expected benefits: higher productivity, staff retention, lower operational costs.
The US Telecommuting Forecast estimated the number of American teleworkers in 2016 at 63 million (Navrátil et al., 2017). A specific indication is the proportion of employers offering part-time telework (in combination with work at the employer's workplace). According to the 2014 National Study of Employers, the share of US businesses, offering this form of work increased from $50 \%$ to $67 \%$ between 2008 and 2014 (Navrátil et al., 2017; Regus, 2017). As reported by the Pan-European Labor Force Survey (LFS), the share of teleworkers is gradually increasing. While in 2009, this share within the EU was $12.2 \%$, in 2016 it was already $14.5 \%$ of all employees. The highest share of teleworkers was recorded in the Netherlands (37\% in 2016) and Denmark (35\%). Bulgarian and Romanian employees use TW least of all EU member countries $(1.1 \%$ and $0.8 \%)$ (Navrátil et al., 2017).

TW is an opportunity for the families with small children, the disabled and, also, for workers based outside of the region, in which their company is located. The reason for a rather low use of TW, despite its obvious advantages in the Czech Republic is primarily a lack of confidence in efficiency and insufficient legislation.

A wide range of remote tools are currently available. The boom in information and communication technologies for TW is mainly due to the constantly falling prices of high-performance computers and mobile devices, along with the increasing ease of use and the penetration of highspeed Internet into everyday life. If these technologies are used effectively, it is possible to work from virtually anywhere with a high-quality Internet connection. One of the prerequisites for TW is the level of IT in the enterprises, specifically the proportion of employees who use smartphones, tablets, 


\section{Journal of Contemporary Management Issues}

laptops and desktop computers. According to available surveys, $17 \%$ of the $\mathrm{EU}$ is equipped to work outside the employer's premises (Navrátil et al., 2017). However, the results of the presented research show that even the size of the enterprise, IT level and time of implementation have no influence on the planning of the workplace (equipment for workers) and the provision of tangible goods.

\subsection{Advantages and disadvantages of TW}

The issue of TW is becoming even more important in the 21 st century, as a need for work-life balance is growing, but the issue of traffic congestion and pollution is also being addressed (Harpaz, 2002). TW provides a way to reconcile the demands of work and family (Maruyama et al., 2009), since with its advent "workers have been given the opportunity to perform some or all of their duties at home or at an alternative location" (Caillier, 2012). It will continue to grow in importance due to increasingly available technologies (Kowalski \& Swanson, 2005; Roukis, 2006).

Although telework can be seen as a typical "magic concept" (Pollitt \& Hupe, 2011), proper implementation is an important factor for ensuring that benefits outweigh the disadvantages (Ammons \& Markham, 2004; Madsen, 2006; Rosalee Carr, 2006). Major et al.'s (2008) study analyzed flexible work organization and found that $60 \%$ of workers perceived their work performance to be better due to TW. Martinez et al. (2007) conducted a research on 156 Spanish companies and found that TW had a positive effect on financial performance and strategic flexibility. Further research on this topic took place in Egypt, where, apart from work security, key factors in work productivity turned out to be work satisfaction, management support and work flexibility (Gamal Aboelmaged \& Mohamed El Subbaugh, 2012).

Companies, promoting TW, improve the public view of society from an environmental perspective (Robert \& Borjesson, 2006) and, also, reduce agency expenses and travel costs (Bailey \& Kurland, 2002). However, the main positive effect is the work-life balance, especially for those who work long distance and also have a family (Golden, 2006; Shockley \& Allen, 2007). However, there are also a number of disadvantages of TW, indicating that it does not automatically improve the quality of life (Moore, 2006). For example, workers may be unable to separate work from family in their home offices, which can increase stress (Russell et al., 2009; Sullivan, 2012)

TW brings many benefits, both to the organization and its employees. Research has confirmed a series of TW benefits, such as increased workers' performance, reduced organizational costs, higher morale and commitment, greater autonomy, reduced commuting time (Brenke, 2016; Caillier, 2012; Cooper \& Kurland, 2002; Fonner \& Roloff, 2010; Masuda et al., 2012, 2012; Redman et al., 2009). On the disadvantage side, research has identified lower-level relations between co-workers and executives, lack of employees' connection with the organization (corporate culture), greater stress for employees, increased working hours, due to more frequent breaks (Cooper \& Kurland, 2002; Gainey et al., 1999; Harker Martin \& MacDonnell, 2012; Messenger, 2017; Reinsch, 1997, 1999; Wiesenfeld et al., 2001). It should be noticed that an advantage for one employee might be a disadvantage for the other. For example, the preference of TW might be related to a person's personality traits. Workers, who are rather individualistic, creative, not distracted at 
home and not seeking contact with the environment, see TW clearly as a benefit. On the other hand, the workers who are team players, like contact and direct communication would be rather frustrated due to TW (Cooper \& Kurland, 2002).

Morgan (2004) states that the biggest barrier to implementing TW in an organization is a negative attitude and an overall managerial view of TW. According to Kowalski and Swanson (2005), TW is not likely to be implemented in organisations where managers do not have enough trust in their employees. Based on a review of 80 studies on TW, Bailey and Kurland (2002) concluded that it was not possible to claim that TW had a positive effect on employee satisfaction and productivity. Similarly, van der Meulen et al. (2014) confirmed that TW does not have a positive effect on productivity when work is evaluated by a supervisor. According to Golden et al. (2006), TW is well-known for its ability to promote work-life balance and to increase work satisfaction. On the other hand, it is usually recommended for the workers seeking career advancement not to telework, as TW indicates a lack of commitment to the careers. To our best knowledge, no research has been carried out in the Czech Republic to assess the factors influencing TW and its implementation in the SMEs.

\section{RESEARCH METHODOLOGY}

The aim of the paper is to analyze the factors, affecting the length of TW implementation in the SMEs in the Czech Republic. In other words, this study is trying to identify the differences between the SMEs that have been using TW for a short period of time and those using it for a long time. In the calculation, $\mathrm{H}_{\mathrm{o}}$ is set that the enterprises do not differ in terms of the observed factors and the alternative hypothesis that the enterprises with observed factor use TW for a longer time. Data collection was conducted in 2019, as part of EF-IGS2017-IGS24B1 research project, supported by the Faculty of Economics in České Budějovice, where 44,000 SME managers were contacted by e-mail. Data were tested, by using the Wilcoxon twosample test (Freeman et al., 2017; Freund et al., 2010) and its asymptotic type. It is a non-parametric two-sample test, which is most often used, when the presumption of data normality is not met. Due to slight violations of normality, for samples larger than 30 , this does not have a major impact on the test results (Devore, 2015; Freeman et al., 2017).

\section{RESEARCH FINDINGS}

The research was carried out in 1,018 SMEs in the Czech Republic, of which 605 (almost 60\%) enterprises use TW with the average length of seven years. This indicates that TW is used more rarely in the Czech Republic, than, e.g. USA, where the number of enterprises using it amounts to more than 70\% (Fried and Hansson, 2014). The mode and median values are five years in both cases, with the standard deviation of 5.3 and the variance of 28.1 years. Half of the enterprises have been using TW in the range between 3 and 10 years, with both values being, simultaneously, time boundaries of the lower and upper quartiles (see Figure 1). The longest time of use is 30 years, due to the historical development in the Czech Republic. 


\section{Journal of Contemporary Management Issues}

Figure 1. Years of telework in SMEs



Source: Authors

Regarding the size of the enterprise, it was not possible to demonstrate any significant differences in the use of TW in SMEs. The micro-enterprises use it up to $56 \%$, the small enterprises up to $62 \%$ and in the medium-sized enterprises, the usage amounts to $59 \%$. More significant differences are found according to industry, where TW is most often used in administrative enterprises (approximately $85 \%$ of all the enterprises), while it is the least often used in agriculture and transport (33\%), as shown in the figure below.

Figure 2. Telework in different industries

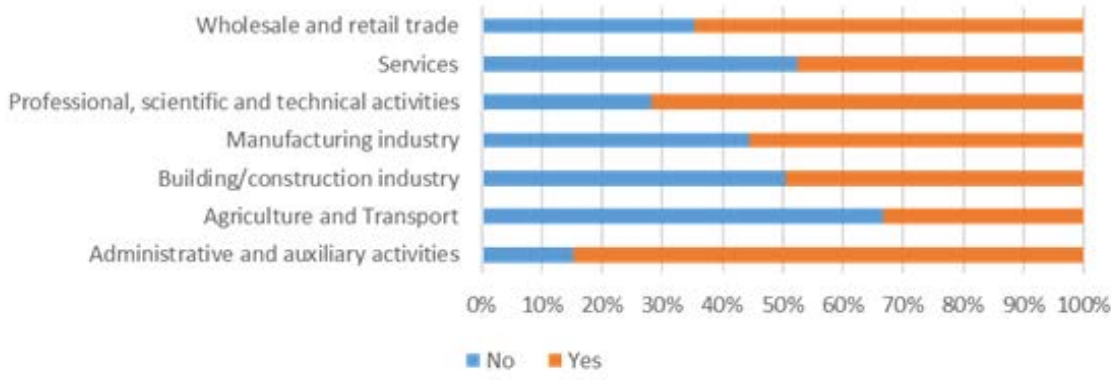

Source: Authors 
Out of all tested factors (family influence, efficiency, flexibility, continuity, nature of work, part-time work, irreplaceability, commuting, disability, work life balance, motivation, lack of staff, illness, distance, parental leave, lower cost, comfort, renting space, home office time schedule, internal TW regulations, IT level, equipment, the cost of home office, loss of private life, absence of team, need for self - control, necessary low work efficiency, IT risks, risk of abuse, absence of control, error rate), several were found to have different effects on the duration of TW. The tested factors, where the Mann-Whitney test failed to show a difference in the number of years of TW implementation, are presented by Table 1 .

The table below summarizes the results of testing $\mathrm{H}_{0}=\mathrm{x}_{0.50}-\mathrm{y}_{0.50}=0$ versus $\mathrm{H}_{\mathrm{A}}=$ $\mathrm{x}_{0.50}>\mathrm{y}_{0.50}$, where $x$ represents the enterprises, implementing the factor, or perceiving it as very significant, while $y$ are the enterprises that do not have it, or do not consider it significant. The table also shows the resulting p-value (tested at the significance level of $95 \%$ ), supplemented by the amount of positive and negative values and the empirical values of $U$ and $Z$ statistics.

Table 1. Mann-Whitney test

\begin{tabular}{|l|c|c|c|c|c|}
\hline Years of telework & Yes & No & U & Z & p-value \\
\hline Greater efficiency & 77600.50 & 105714.5 & 38919.50 & 2.32018 & 0.020332 \\
\hline $\begin{array}{l}\text { Monitoring is only performed } \\
\text { according to the results }\end{array}$ & 69484.00 & 113831.0 & 37976.00 & 1.959070 & 0.049895 \\
\hline $\begin{array}{l}\text { They see the possibility of abuse as a } \\
\text { disadvantage }\end{array}$ & 25674.00 & 82206.00 & 17799.00 & -2.64395 & 0.008195 \\
\hline They use internal regulations for TW & 48209.50 & 133896.5 & 28785.50 & 2.41702 & 0.015649 \\
\hline $\begin{array}{l}\text { The main advantage is in higher } \\
\text { operability }\end{array}$ & 46427.50 & 62383.50 & 23043.50 & 2.10445 & 0.035340 \\
\hline $\begin{array}{l}\text { Introduced due to family obligations } \\
\text { (having children) }\end{array}$ & 20036.00 & 163279.0 & 17110.00 & -2.09947 & 0.035777 \\
\hline
\end{tabular}

Source: Authors

As shown by Table 1, the enterprises with introduced TW, due to better efficiency and use it longer, so it can be assumed that the efficiency gains are the main impetus for the enterprises to introduce TW, unlike, e.g. shortage of workers, commuting, illness, benefits and lower costs. Regarding these factors, the difference in the number of years of implementation in the SMEs was not proved. On the other hand, the factor of "better work-life balance", taking into account the employee-child relationship, as the main reason for the introduction, is mentioned by the enterprises, using TW for considerably shorter time than those that do not mention this factor. It is assumed the enterprises are currently taking this new direction. The difference in both groups is reported by the figure below. The enterprises, revealing the difference as not significant report the maximum of 30 years and half of the values are ranked up to 10 years; while the lower quartile in both groups is the same. 


\section{Journal of Contemporary Management Issues}

Figure 3. Boxplots of TW length in years vs. internal regulations (left) and family obligations (right)

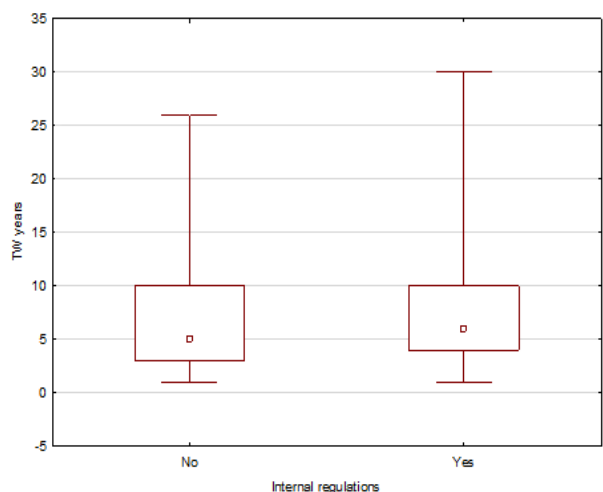

Source: Authors

Other factor, affecting the length of implementation of TW include "internal regulations". It is proved that the enterprises with an internal TW regulation use it longer, as shown by Table 1 and Figure 3. The quartiles of the two groups of SMEs are very similar, but the median is higher for the enterprises with internal regulations, as the lower limit for half the data. This result is logically determined by the efforts of the enterprises to increase TW regulation. The Mann-Whitney test also showed the difference, in terms of the advantages of TW for the enterprises. The enterprises, seeing the "higher operability" as the main advantage of TW use it longer. On the other hand, the enterprises, seeing lower costs, work satisfaction, work-life balance and time savings as the main advantages did not have a significant relationship with the length of TW use.

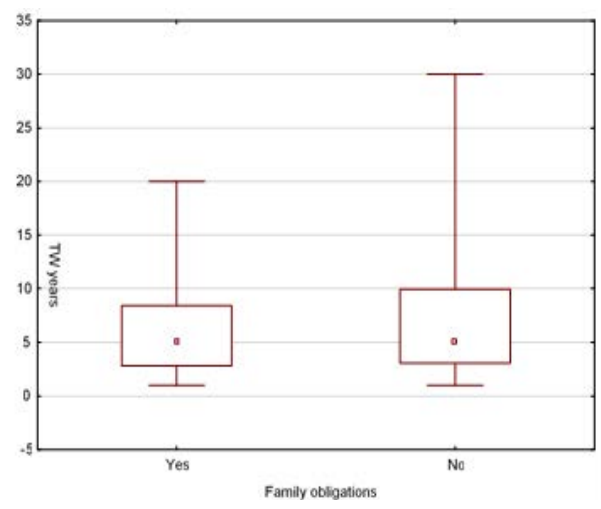

Another research topic is the comparison of the enterprises in terms of TW monitoring. The enterprises, monitoring only the outcomes (results) of employee work reach a higher length of TW implementation in years, as shown by Figure 4 . On the other hand, it was not possible to prove differences in the enterprises that monitor the work of employees on a computer-by-computer basis, individually and those that do not perform any monitoring due to the trust they put in their employees. It can, therefore, be concluded that after a longer period of time, the employers, using TW, move to the simplest method of its monitoring, based on employee results and gradually eliminate individual control and continuous random checks. 
Figure 4. Boxplot TW length in years vs. the risk of abuse (left) and the type of control (right)

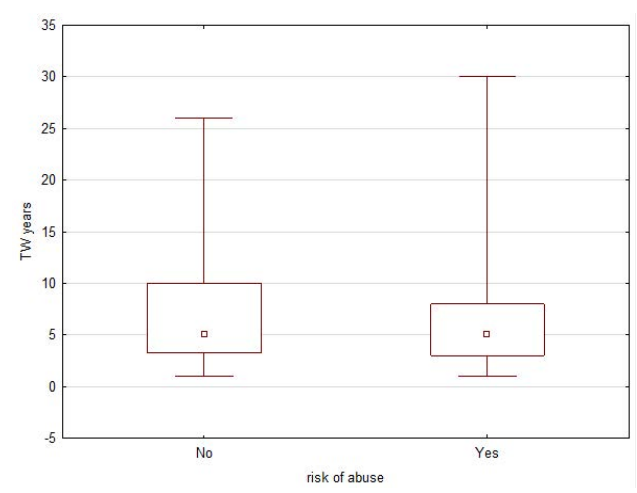

Source: Authors

The last part of the research focuses on the disadvantages of TW. In terms of the number of years of TW implementation, the differences were not proved between the enterprises reporting the following disadvantages: loss of private life, absence of a team, strong self-control related to OSH (Occupational safety and health), IT and costs. On the contrary, it was possible to prove the difference between the enterprises that are worried about the risk of data misuse, with TW established for a shorter period of time, as shown by Figure 4.

\section{CONCLUSION}

TW owes its growing popularity mainly to the development of technology and the emerging generation of millennials, which cares more about personal freedom and self-realization than previous generations. Allowing TW is and will be a very important factor in finding work for the 'Generation Y'. It can be assumed that it will be even more important to for the 'Generation Z'. The research carried out in 1,018 SMEs in the Czech Republic shows that almost $60 \%$ of the enterprises use TW in some way. On average, they have been using it for seven years.

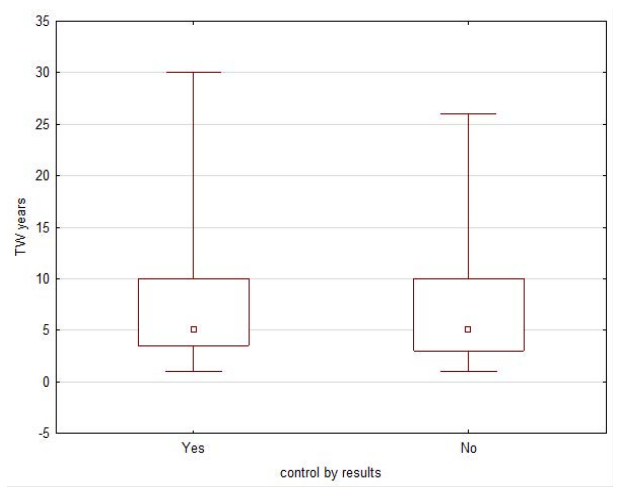

The future research tasks are related to comparing the situation of TW before the coronavirus disease (Covid-19), as described by this study, and after its emergence, for the same organizations. As the results of other studies suggest, this period had a great influence on TW. For instance, industrial sectors, such as transportation and storage, accommodation and food services, wholesale, retail and repair provide relatively still few opportunities for people to telework. Other sectors, such as information and communication industries, professional, scientific and technical activities, financial and insurance activities, and real estate activities, provide more TW opportunities. TW has also been used more frequently by more educated workers, as well as by the older generations, which is more at risk due to the current pandemic (Office for National Statistics, 2020). The measures aimed at protecting the citizens from the coronavirus disease (Covid-19) seem to have added a boost to the implementation of TW and research has shown that this will also add major cyber security issues to enterprises of all sizes (Tabrez, 2020). At the beginning of 2020, several governments recommended that companies facilitate TW to avoid social contact among employees. For instance, the Spanish Health Minister 


\section{Journal of Contemporary Management Issues}

asked companies to promote telework, as a measure to face the coronavirus in Spain and several protocols were published to help companies in their implementation of telework (Belzunegui-Eraso \& Erro-Garcés, 2020)

\section{References}

1. Ammons, S. K., \& Markham, W. T. (2004). Working at home: Experiences of skilled white collar workers. Sociological Spectrum, 24(2), 191-238. https://doi. org/10.1080/02732170490271744

2. AMSP. (2010). Názory podnikateli̊ $k$ politice zaměstnanosti a pracovnímu právu. AMSP. http://www.amsp.cz/ uploads/Pruzkum_c7.pdf

3. Bailey, D. E., \& Kurland, N. B. (2002). A review of telework research: Findings, new directions, and lessons for the study of modern work. Journal of Organizational Behavior, 23(4), 383-400. https://doi.org/10.1002/ job. 144

4. Belzunegui-Eraso, A., \& Erro-Garcés, A. (2020). TW in the Context of the Covid-19 Crisis. Sustainability, 12(9), 3662. https://doi.org/10.3390/ su12093662

5. Brenke, K. (2016). Home offices: Plenty of untapped potential. DIW Economic Bulletin, 6(8), 94-104.

6. Caillier, J. G. (2012). The Impact of TW on Work Motivation in a U.S. Federal Government Agency. The American Review of Public Administration, 42(4), 461-480. https://doi. org/10.1177/0275074011409394

7. Cooper, C. D., \& Kurland, N. B. (2002). Telecommuting, professional isolation, and employee development in public and private organizations. Journal of Organizational Behavior, 23(4), 511-532. https://doi. org/10.1002/job.145

8. Devore, J. L. (2015). Probability and Statistics for Engineering and the Sciences (9 edition). Brooks Cole.

9. Eurostat. (2020). Working from home in the EU. Eurostat. https://ec.europa.eu/ eurostat/web/products-eurostat-news/-/ DDN-20180620-1

10. Fitzer, M. M. (1997). Managing from Afar: Performance and Rewards in a Telecommuting Environment. Compensation \& Benefits Review, 29(1), 65-73. https://doi. org/10.1177/088636879702900110

11. Fonner, K. L., \& Roloff, M. E. (2010). Why Teleworkers are More Satisfied with Their Jobs than are OfficeBased Workers: When Less Contact is Beneficial. Journal of Applied Communication Research, 38(4), 336361. https://doi.org/10.1080/00909882. 2010.513998

12. Freeman, J., Shoesmith, E., Sweeney, D., Anderson, D., \& Williams, T. (2017). Statistics for Business and Economics (4th Revised edition edition). Cengage Learning EMEA.

13. Freund, R. J., Wilson, W. J., \& Mohr, D. L. (2010). Statistical methods (3rd ed). Elsevier.

14. Fried, J., \& Hansson, D. H. (2014). Práce na dálku: Zn.: Kancelár zbytečná. Jan Melvil.

15. Gainey, T. W., Kelley, D. E., \& Hill, J. A. (1999). Telecommuting's Impact on Corporate Culture and Individual Workers: Examining the Effect of Employee Isolation. SAM Advanced Management Journal, 64(4), 4. Gale Academic Onefile. 
16. Gamal Aboelmaged, M., \& Mohamed El Subbaugh, S. (2012). Factors influencing perceived productivity of Egyptian teleworkers: An empirical study. Measuring Business Excellence, 16(2), 3-22. https://doi. org/10.1108/13683041211230285

17. Golden, T. D. (2006). The role of relationships in understanding telecommuter satisfaction. Journal of Organizational Behavior, 27(3), 319340. https://doi.org/10.1002/job.369

18. Harker Martin, B., \& MacDonnell, R. (2012). Is telework effective for organizations?: A meta-analysis of empirical research on perceptions of telework and organizational outcomes. Management Research Review, 35(7), 602-616. https://doi. org/10.1108/01409171211238820

19. Harpaz, I. (2002). Advantages and disadvantages of telecommuting for the individual, organization and society. Work Study, 51(2), 74-80. https://doi. org/10.1108/00438020210418791

20. Chung, H., \& van der Horst, M. (2018). Women's employment patterns after childbirth and the perceived access to and use of flexitime and TW. Human Relations, 71(1), 47-72. https://doi. org/10.1177/0018726717713828

21. Kotíková, J., Kotrusová, M., \& Vychová, H. (2013). Flexibilní formy práce ve vybraných zemích $E U$. Výzkumný ústav práce a sociálních věcí, v.v.i. http://praha.vupsv.cz/ Fulltext/vz_366.pdf

22. Kowalski, B. K., \& Swanson, J. A. (2005). Critical success factors in developing TW programs. Benchmarking: An International Journal, 12(3), 236-249. https://doi. org/10.1108/14635770510600357
23. KPMG. (2013). Populárni home office: Pracovat z domova chtěji tř čtvrtiny Čechů, Marketingové noviny.cz. http:// www.marketingovenoviny.cz/popularni-home-office-pracovat-z-domovachteji-tri-ctvrtiny-cechu/

24. Madsen, S. R. (2006). Work and family conflict: Can home-based TW make a difference? International Journal of Organization Theory \& Behavior, 9(3), 307-350. https://doi.org/10.1108/ IJOTB-09-03-2006-B002

25. Major, D. A., Verive, J. M., \& Joice, W. (2008). Telework as a dependent care solution: Examining current practice to improve telework management strategies. The Psychologist-Manager Journal, 11(1), 65-91. https://doi. org/10.1080/10887150801967134

26. Martinez-Sanchez, A., Perez-Perez, M., de-Luis-Carnicer, P., \& VelaJimenez, M. J. (2007). Telework, human resource flexibility and firm performance. New Technology, Work and Employment, 22, 208-223.

27. Maruyama, T., Hopkinson, P. G., \& James, P. W. (2009). A multivariate analysis of work-life balance outcomes from a large-scale telework programme. New Technology, Work and Employment, 24(1), 76-88. https://doi. org/10.1111/j.1468-005X.2008.00219.x

28. Masuda, A. D., et al. (2012). Flexible Work Arrangements Availability and their Relationship with Work-toFamily Conflict, Job Satisfaction, and Turnover Intentions: A Comparison of Three Country Clusters, Applied Psychology, 61(1), 1-29. https://doi. org/10.1111/j.1464-0597.2011.00453.x

29. Matos, K., \& Galinsky, E. (2014). National Study of Employers. Families and Work Institute. http:// 


\section{Journal of Contemporary Management Issues}

familiesandwork.org/downloads/2014N ationalStudyOfEmployers.pdf

30. Messenger, J. C. (2017). Working anytime anywhere: The effects on the world of work. IUSLabor.

31. Moore, J. (2006). Homeworking and work-life balance: Does it add to quality of life? European Review of Applied Psychology, 56(1), 5-13. https://doi. org/10.1016/j.erap.2005.02.013

32. Morgan, R. E. (2004). TW: An assessment of the benefits and challenges. European Business Review, 16(4), 344-357. https://doi. org/10.1108/09555340410699613

33. Navrátil, M., Hladká, M., Dušánek, D., \& Duspivová, K. (2017). Problémy při práci na dálku a jejich řešení pro zaměstnance. Trexima.

34. Office for National Statistics. (2020). Coronavirus and homeworking in the UK labour market. http://www.ons. gov.uk/employmentandlabourmarket/ peopleinwork/employmentandemployeetypes/articles/coronavirusandhomeworkingintheuklabourmarket/2019

35. Plantenga, J., Remery, C., DirectorateGeneral for Employment, Social Affairs and Equal Opportunities (Author), European Commission (Ed.). (2010). Flexible working time arrangements and gender equality: A comparative review of 30 European countries. Publ. Off. of the Europ. Union.

36. Pollitt, C., \& Hupe, P. (2011). Talking About Government: The role of magic concepts. Public Management Review, 13(5), 641-658. https://doi.org/10.1080 $/ 14719037.2010 .532963$

37. Redman, T., Snape, E., \& Ashurst, C. (2009). Location, Location, Location: Does Place of Work Really Matter? British Journal of Management,
20, S171-S181. https://doi. org/10.1111/j.1467-8551.2008.00640.x

38. Regus. (2017). The Workplace Revolution - a picture of flexible working. https://www.regus.com/work-us/ en-us/the-workplace-revolution/

39. Reinsch, N. L. (1997). Relationships Between Telecommuting Workers and Their Managers: An Exploratory Study. Journal of Business Communication, 34(4), 343-367. https://doi org/10.1177/002194369703400402

40. Reinsch, N. L. (1999). Selected Communication Variables and Telecommuting Participation Decisions: Data from Telecommuting Workers. Journal of Business Communication, 36(3), 247-260. https://doi. org/10.1177/002194369903600302

41. Robèrt, M., \& Börjesson, M. (2006). Company Incentives and Tools for Promoting Telecommuting. Environment and Behavior, 38(4), 521-549. https://doi. org/10.1177/0013916505283422

42. Rosalee Carr, M. (2006). Telecommuting: Alternative strategies for the Jamaican libraries. The Electronic Library, 24(3), 380-388. https://doi. org/10.1108/02640470610671222

43. Roukis, G. S. (2006). Globalization, organizational opaqueness and conspiracy. Journal of Management Development, 25(10), 970-980. https:// doi.org/10.1108/02621710610708595

44. Russell, H., O’Connell, P. J., \& McGinnity, F. (2009). The Impact of Flexible Working Arrangements on Work-life Conflict and Work Pressure in Ireland. Gender, Work \& Organization, 16(1), 73-97. https://doi. org/10.1111/j.1468-0432.2008.00431.x 
45. Shockley, K. M., \& Allen, T. D. (2007). When flexibility helps: Another look at the availability of flexible work arrangements and work-family conflict. Journal of Vocational Behavior, 71(3), 479-493. https://doi.org/10.1016/j. jvb.2007.08.006

46. Smith, S. A., Patmos, A., \& Pitts, M. J. (2018). Communication and TW: A Study of Communication Channel Satisfaction, Personality, and Job Satisfaction for TW Employees. International Journal of Business Communication, 55(1), 44-68. https:// doi.org/10.1177/2329488415589101

47. Spellman, F. R., \& Whiting, N. E. (2014). Handbook of mathematics and statistics for the environment. CRC Press, Taylor \& Francis Group.

48. Sullivan, C. (2012). Remote Working and Work-Life Balance. In N. P. Reilly, M. J. Sirgy, \& C. A. Gorman (Ed.), Work and Quality of Life (275290). Springer Netherlands. https://doi. org/10.1007/978-94-007-4059-4_15

49. Tabrez, A. (2020). Corona Virus (COVID-19) Pandemic and Work from Home: Challenges of Cybercrimes and Cybersecurity. http://dx.doi. org/10.2139/ssrn.3568830

50. USA Telework Enhancement Act of 2010 Chapter 65 - Telework. (2010). https://www.gpo.gov/fdsys/pkg/ BILLS-111hr1722 enr/pdf/BILLS111hr1722enr.pdf

51. Václavková, L., Vysoká škola ekonomická v Praze, \& Podnikohospodářská fakulta. (2007). Specifika řízení lidských zdroju $v$ malých a středních podnicích a neziskových organizacích: Výzkumná zpráva z projektu IGA 18/05. Oeconomica.

52. van der Meulen, N., van Baalen, P., \& van Heck, E. (2014). No Place Like Home: The Effect of Telework Gains on Knowledge Worker Productivity. Academy of Management Proceedings, 2014(1), 15944 . https://doi. org/10.5465/ambpp.2014.15944abstract

53. Wiesenfeld, B. M., Raghuram, S., \& Garud, R. (2001). Organizational identification among virtual workers: The role of need for affiliation and perceived work-based social support. Journal of Management, 27(2), 213-229. https://doi. org/10.1177/014920630102700205 


\title{
Journal of Contemporary Management Issues
}

\author{
RAD NA DALJINU U MALIM I SREDNJIM \\ PODUZEĆIMA U ČEŠKOJ REPUBLICI PRIJE \\ POČETKA KRIZE KORONAVIRUSA
}

\begin{abstract}
Sažetak
Zbog razvoja novih informacijskih $i$ komunikacijskih tehnologija, danas postaje moguće razdvojiti posao od vremena i mjesta njegova obavljanja te koristiti nove mogućnosti za njegovu organizaciju. Jedna od opcija je i rad na daljinu, koji se trenutno provodi širom Europe, zbog uvjeta, koji nastaju zbog pandemije koronavirusa. Cilj rada je dvostruki: (a) analizirati niz čimbenika (veličinu poduzeća, vlasništvo, formalizaciju strategije, projektnu usmjerenost poduzeća, posebne potrebe zaposlenika, odnos radnog i privatnog života, pogodnosti za zaposlenike, nedostatak radne snage, bolest zaposlenika, niže troškove, mogućnost opuštanja i komfora na radnom mjestu, najam poslovnog prostora i razinu informatičke opremljenosti), koji djeluju na duljinu implementacije rada na daljinu u malim $i$ srednjim poduzećima (MSP) te (b) bolje odrediti razlike između MSP-a, $u$ kojima je rad na daljinu uveden $u$ kraćem, u odnosu na MSP-ove, koji su ga uvodili dulje vrijeme. Od ukupno analiziranog 31 čimbenika, za šest (implementacija rada na daljinu zbog više učinkovitosti; nadzor samo nad rezultatima rada; menadžment shvaća mogućnosti zlouporabe rada na daljinu; poduzeća koriste interne propise za rad na daljinu; menadžeri uviđaju da je veća operativna fleksibilnost temeljna prednost rada na daljinu; uvođenje rada na daljinu zbog uravnoteženja rada i obiteljskog života) utvrđeno je da imaju različito djelovanje na duljinu implementacije rada na daljinu. Ukupno je 44,000 MSP-ova iz Češke Republike pozvano na sudjelovanje u istraživanju. Podaci su prikupljeni od 1,018 poduzeća, od čega je $60 \%$ aktivno koristilo rad na daljinu, i to u prosječnom trajanju od sedam godina.
\end{abstract}

Ključne riječi: rad na daljinu, karijera, mala i srednja poduzeća (MSP), menadžment, rad od kuće 